\title{
Notulae to the Italian native vascular flora: 10
}

\author{
Fabrizio Bartolucci', Gianniantonio Domina², Simonetta Bagella ${ }^{3}$,
} Giuseppina Barberis ${ }^{4}$, Ian Briozzo ${ }^{4}$, Mario Calbi ${ }^{5}$, Maria C. Caria ${ }^{3}$, Viviana Cavallaro ${ }^{6}$, Giuseppina Chianese ${ }^{7}$, Carlo Cibei ${ }^{4}$, Fabio Conti', Davide Dagnino ${ }^{4}$, Assunta Esposito ${ }^{8}$, Gabriele Galasso9, Valeria Giacanelli ${ }^{10}$, Luigi Forte ${ }^{6}$, Günter Gottschlich"1, Edda Lattanzi'2, Daniela Longo ${ }^{4}$, Giacomo Mei ${ }^{13}$, Marco Merli ${ }^{14}$, Simone Orsenigo ${ }^{15}$, Gian Battista Pau ${ }^{16}$, Gaetano Pazienza ${ }^{17}$, Simonetta Peccenini ${ }^{4}$, Stefania Pisanu ${ }^{3}$, Giovanni Rivieccio ${ }^{18}$, Francesco Roma-Marzio ${ }^{19}$, Filippo Scafidi ${ }^{2}$, Federico Selvi ${ }^{20}$, Adriano Stinca ${ }^{8}$, Claudia Turcato ${ }^{4}$, Chiara Nepi ${ }^{21}$

I Centro Ricerche Floristiche dell'Appennino (Università di Camerino - Parco Nazionale del Gran Sasso e Monti della Laga), San Colombo, 67021 Barisciano (L'Aquila), Italy 2 Dipartimento di Scienze Agrarie, Alimentari e Forestali (SAAF), Università di Palermo, Viale delle Scienze, edificio 4, 90128 Palermo, Italy 3 Dipartimento di Chimica e Farmacia, Università di Sassari, Via Piandanna 4, 07100 Sassari, Italy 4 Dipartimento di Scienze della Terra, dell'Ambiente e della Vita, Università di Genova, Corso Europa 26, 16132 Genova, Italy 5 Via C. Pisacane 16/8, 16129 Genova, Italy 6 Dipartimento di Biologia - Campus Universitario E. Quagliariello, Università di Bari A. Moro, Via E. Orabona 4, 70125 Bari, Italy 7 Centro Museale Musei delle Scienze Agrarie (MUSA), Università di Napoli Federico II, Via Università 100, 80055 Portici (Napoli), Italy 8 Dipartimento di Scienze e Tecnologie Ambientali, Biologiche e Farmaceutiche, Università della Campania Luigi Vanvitelli, Via A. Vivaldi 43, 81100 Caserta, Italy 9 Sezione di Botanica, Museo di Storia Naturale di Milano, Corso Venezia 55, 20121 Milano, Italy 10 Dipartimento per il Monitoraggio e la Tutela dell'Ambiente e per la Conservazione della Biodiversità, Istituto Superiore per la Protezione e la Ricerca Ambientale (ISPRA), Via V. Brancati 60, 00144 Roma, Italy I I Hermann-Kurz Strasse 35, D-72074 Tübingen, Germany 12 Via V.o Cerulli 59, 00143 Roma, Italy 13 Dipartimento di Scienze Agrarie, Alimentari ed Ambientali, Università Politecnica delle Marche, Via Brecce Bianche 10, 60131, Ancona, Italy 14 Via dei Caputei 7, 38070 Stenico fraz. Scelmo (Trento), Italy 15 Dipartimento di Scienze della Terra e dell'Ambiente, Università degli Studi di Pavia, Via Sant'Epifanio 14, 27100, Pavia, Italy 16 Loc. Ofricatu snc, 08029 Siniscola (Nuoro), Italy 17 Museo Orto Botanico - Campus Universitario E. Quagliariello, Università di Bari Aldo Moro, Via E. Orabona 4, 70125 Bari, Italy 18 Nucleo di Ricerca sulla Desertificazione, Università di Sassari, Via E. de Nicola snc, 07100 Sassari, Italy 19 Sistema Museale di Ateneo, Orto e Museo Botanico, Università di Pisa, Via L. Ghini 13, 56126 Pisa, Italy 20 Dipartimento di Scienze e Tecnologie Agrarie, Alimentari, Ambientali e Forestali, Università di Firenze, Piazzale delle Cascine 28, 50144, Firenze, Italy 21 Sistema Museale di Ateneo, Università di Firenze, Via G. La Pira 4, 50121 Firenze, Italy

Corresponding author: Fabrizio Bartolucci (fabrizio.bartolucci@gmail.com)

Copyright Fabrizio Bartolucci et al. This is an open access article distributed under the terms of the Creative Commons Attribution License (CC BY 4.0), which permits unrestricted use, distribution, and reproduction in any medium, provided the original author and source are credited. 
Academic editor: M. Arnedo | Received 13 November 2020 | Accepted 16 November 2020 | Published 26 November 2020

Citation: Bartolucci F, Domina G, Bagella S, Barberis G, Briozzo I, Calbi M, Caria MC, Cavallaro V, Chianese G, Cibei C, Conti F, Dagnino D, Esposito A, Galasso G, Giacanelli V, Forte L, Gottschlich G, Lattanzi E, Longo D, Mei G, Merli M, Orsenigo S, Pau GB, Pazienza G, Peccenini S, Pisanu S, Rivieccio G, Roma-Marzio F, Scafidi F, Selvi F, Stinca A, Turcato C, Nepi C (2020) Notulae to the Italian native vascular flora: 10. Italian Botanist 10: 47-55. https:// doi.org/10.3897/italianbotanist.10.60743

\begin{abstract}
In this contribution, new data concerning the distribution of native vascular flora in Italy are presented. It includes new records, confirmations, exclusions, and status changes to the Italian administrative regions for taxa in the genera Artemisia, Chaetonychia, Cirsium, Cynanchum, Genista, Hieracium, Iberis, Melica, Misopates, Myosotis, Thalictrum, Trifolium, Utricularia, Veronica, and Vicia. Nomenclatural and distribution updates, published elsewhere, and corrigenda are provided as supplementary material.
\end{abstract}

\title{
Keywords
}

Endemic, Floristic data, Italy

\section{How to contribute}

The text for the new records should be submitted electronically to Chiara Nepi (chiara. nepi@unifi.it). The corresponding specimen along with its scan or photograph have to be sent to FI Herbarium: Sezione di Botanica "Filippo Parlatore" del Museo di Storia Naturale, Via G. La Pira 4, 50121 Firenze (Italy). Those texts concerning nomenclatural novelties (typifications only for accepted names), status changes, exclusions, and confirmations should be submitted electronically to: Fabrizio Bartolucci (fabrizio.bartolucci@gmail.com). Each text should be within 1,000 characters (spaces included).

\section{Floristic records}

\section{Artemisia caerulescens L. subsp. cretacea (Fiori) Brilli-Catt. \& Gubellini (Asteraceae)}

+ CAL: Caccuri (Crotone) lungo il Torrente Lepre presso loc. Bagni di Repote (WGS84: 39.218358N; 16.836357E), calanco, $145 \mathrm{~m}, 11$ October 2018, A. Stinca (FI, PORUN-Stinca). - Species and subspecies new for the flora of Calabria.

A. Stinca, G. Chianese, A. Esposito 


\section{Chaetonychia cymosa (L.) Sweet (Caryophyllaceae)}

+ SAR: Siniscola (Nuoro), Loc. Petriolu (WGS84: 40.488720N; 9.810100E), margine di una vecchia carraia, esp. S, 12 m s.l.m., 17 May 2020, G.B. Pau (SS). - Species confirmed for the flora of Sardegna.

Chaetonychia cymosa is a western-Mediterranean species (Pignatti et al. 2017), native to the Iberian Peninsula (Balearic Islands excluded), south of France, Corsica, Sardegna, Morocco, and Tunisia (Soriano Martin 1997). It was recorded for the first time in Sardegna in 1840 by Domenico Lisa (Mattirolo 1893), and later confirmed by Fiori (1923) and by Pignatti et al. (2017). However, according to Arrigoni (2010) and Bartolucci et al. (2018), this species was known only due to historical records.

G.B. Pau, S. Bagella

\section{Cirsium vulgare (Savi) Ten. subsp. vulgare (Asteraceae)}

+ CAM: Castellammare di Stabia (Napoli), località Quisisana (WGS84: 40.686260N; 14.481711E), bordo strada, 172 m, 22 June 2020, A. Stinca (FI, PORUN-Stinca). Subspecies new for the flora of Campania.

A. Stinca, G. Mei, A. Esposito

\section{Cynanchum acutum L. subsp. acutum (Apocynaceae)}

+ ABR: Città Sant'Angelo (Pescara), Marina di Città Sant'Angelo, riva sinistra del Fiume Saline presso la foce, sull'argine (WGS84: 42.525742N; 14.150094E), spiaggia, 1 m, no exp., 8 May 2018, leg. G. Galasso, det. G. Galasso, E. Banfi (MSNM); ibidem, 16 May 2020, F. Conti, V. Giacanelli (APP, MSNM); ibidem, 29 May 2020, F. Conti, V. Giacanelli (FI, APP). - Subspecies new for the flora of Abruzzo.

F. Conti, V. Giacanelli, G. Galasso

\section{Genista etnensis (Raf.) DC. (Fabaceae)}

+ (NAT) TOS: Civitella Marittima (Grosseto) (WGS84: 42.994981 N; 11.289629 E), scarpata stradale presso lo svincolo sulla strada Siena-Grosseto, 278 m, 6 Jun 2020, F. Selvi 3980 (FI). - Naturalized regional alien species new for the flora of Toscana.

In the locality reported here, a few plants of this species, otherwise endemic to Sicilia and Sardegna, were introduced about 20 years ago for the stabilization of a road embankment. At present, it occurs with a few old plants and $c a$. 15 younger individuals in the close surroundings, established by natural regeneration. In early June 2020, these plants bore flowers and young fruits, showing their reproductive capacity under local conditions. 
Hieracium ramosissimum Schleich. ex Hegetschw. subsp. conringiifolium (Arv.Touv.) Zahn (Asteraceae)

+ EMR: Agnelli, Coli (Piacenza), margine strada (WGS84: 44.72341N; 9.43767E), 980 m s.l.m., exp. Nord, 10 July 2019, S. Orsenigo, det. G. Gottschlich (PAV, Herb. Orsenigo). - Subspecies confirmed for the flora of Emilia-Romagna.

Hieracium ramosissimum subsp. conringiifolium was reported in Emilia-Romagna as doubtfully occurring (Bartolucci et al. 2018). Some historical records (sub H. conringiifolium Arv.) were reported for the province of Piacenza by Bracchi and Romani (2010), who referred to Pavarino (1915) and Pavesi (1906). In particular, the latter author collected this subspecies in the area of Sassi Neri, between Lombardia and the Emilia-Romagna border, in an area probably falling within the municipality of Bobbio (Piacenza).

S. Orsenigo, G. Gottschlich

\section{Iberis semperflorens $\mathrm{L}$. (Brassicaceae)}

+ (CAS) TAA: Torbole (Trento) (WGS 45.870667N; 10.87834667E), pendio esposto a sud, $111 \mathrm{~m}$, 25 January 2020, M. Merli (FI, ROV, Herb. Merli). - Casual regional alien species new for the flora of Trentino-Alto Adige.

M. Merli, G. Galasso

\section{Melica transsilvanica Schur subsp. klokovii Tzvelev. (Poaceae)}

+ LIG: Magliolo (Savona), impluvio del Torrente Maremola (WGS84: 44.19523907N; 8.2349215E), affioramento di dolomia, $270 \mathrm{~m}, 7$ December 2019, A. Alberto, A. Baroni, F. Baroni, I. Briozzo, S. Briozzo, C. Cibei, D. Dagnino, D. Dozza, D. Longo, M. Ottonello, R. Paneri, S. Peccenini, E. Rodi (GE No. 1613, FI). - Subspecies new for the flora of Liguria.

No information was available on the occurrence of Melica transsilvanica subspecies in Liguria (Bartolucci et al. 2018).

D. Dagnino, C. Cibei

\section{Misopates calycinum Rothm. (Plantaginaceae)}

+ LIG: Sori (Genova), sotto la Torre Saracena di Polanesi (WGS84: 44.367555N; 9.122138E), fasce abbandonate, $170 \mathrm{~m}, 17$ June 2020, M. Calbi (GE No. 2566). Species confirmed for the flora of Liguria.

The most recent report dates back to Gismondi (1949) for a locality (Mulinetti di Recco, along the railway) not far from the place of the new discovery.

G. Barberis, M. Calbi 


\section{Myosotis sylvatica Hoffm. subsp. subarvensis Grau (Boraginaceae)}

+ CAM: Montevergine (Avellino) (WGS84: 40.937195N; 14.724666E), radura all'interno di una faggeta, 1315 m, 07 July 2016, F. Scafidi (FI). - Subspecies new for the flora of Campania.

This taxon has been identified according to Grau (1964).

F. Scafidi

\section{Thalictrum minus L. (Ranunculaceae)}

+ PUG: Gravina in Puglia (Bari), Pulicchio di Gravina (WGS84: 40.904633N; 16.422215E), $477 \mathrm{~m}$ s.l.m., radura di rimboschimento sul fondo del Pulicchio di Gravina, 13 June 2020, leg. G. Pazienza, det. G. Pazienza, L. Forte, V. Cavallaro (FI; BI No. 42341) - Species confirmed for the flora of Puglia.

In Licht (2018) and Licht and Wagensommer (2020), Thalictrum minus was reported as probably occurring in Puglia, in the Gargano Promontory, based on Hand (2001). According to Bartolucci et al. (2018), T. minus L. subsp. minus was reported in Puglia as no longer recorded. Palanza (1900) reported it under the name "T. elatum (Jacq.) Bert." "Nei pascoli del Pulicchio alle Murgie di Gravina; alla riva dell'Ofanto nel Barlettano". The new specimens and a revision of the specimens collected by Palanza (BI Nos. 44166, 44167 and 44240) led us to attribute all of them to T. minus L., but left unsolved the attribution to a subspecies.

G. Pazienza, L. Forte, V. Cavallaro

\section{Trifolium bocconei Savi (Fabaceae)}

+ LIG: Ameglia (La Spezia), "IT 1345109 Montemarcello", nei pressi del sentiero per Punta Bianca (WGS84: 44.038015N; 9.973765E), prateria xerofila mediterranea (Habitat Natura 2000 cod.6220), 85 m, 9 August 2019, D. Dagnino, C. Turcato, (GE No. 1359); Calice al Cornoviglio (La Spezia) Loc. Martinello, lungo il torrente Usurana, 3 June 2005, E. Lattanzi, (Herb. Lattanzi). - Species confirmed for the flora of Liguria.

Several Ligurian localities were reported by De Notaris (1844), Bertoloni (18501853), and in Ottone Penzig's handwritten notes found on a copy of De Notaris (1844), stored in the library of the University of Genova. Although this species occurs in most of the Mediterranean Italian regions, it was no longer recorded for Liguria (Bartolucci et al. 2018).

E. Lattanzi, D. Dagnino, C. Turcato 


\section{Utricularia vulgaris L. (Lentibulariaceae)}

+ SAR: Sorso (Sassari), Platamona lagoon (WGS84: 40.815739N; 8.490230E), vegetazione peristagnale a dominanza di Cladium mariscus, $2 \mathrm{~m}$ s.l.m, 24 June 2020, G. Rivieccio, M.C. Caria, S. Pisanu, S. Bagella (SS). - Species confirmed for the flora of Sardegna.

Although this species was reported for Sardegna by Giau (1986), its presence in the island was questioned and only the presence of Utricularia australis R.Br. was confirmed (Desfayes 2008; Arrigoni 2013; Bartolucci et al. 2018; Bagella et al. 2020; Orrù et al. 2020). We localized a population of $U$. vulgaris alongside the Platamona lagoon, in Habitat 7210* "Calcareous fens with Cladium mariscus and species of the Caricion davallianae" (Gigante et al. 2019).

G. Rivieccio, M.C. Caria, S. Pisanu, S. Bagella

\section{Veronica vindobonensis (M.A.Fisch.) M.A.Fisch. (Plantaginaceae)}

- ITALIA (TOS). - Species to be excluded from the flora of Italy.

Veronica vindobonensis is an East European species, reported as native in Italy by Walters and Webb (1972) and by Marhold (2011+), but not included in the recent checklists of the Italian vascular flora (Bartolucci et al. 2018, Galasso et al. 2018), nor was it reported by Pignatti et al. (2018). Recently, Arrigoni (2020) listed this species as non-native and doubtfully occurring in Toscana, based on a record published by Del Prete and Tomaselli (1982) for the Apuan Alps that, to the best of my knowledge, is the only verifiable record for Italy. In PI we traced the specimen cited by these authors, but it is actually attributable to $V$. chamaedrys L. subsp. chamaedrys (http://erbario. unipi.it/it/erbario/view?id=1623472). Accordingly, I exclude $V$. vindobonensis for the flora of Italy.

F. Roma-Marzio

\section{Vicia johannis Tamamsch. (Fabaceae)}

+ LIG: Chiusanico (Imperia), sopra Borgata Castello (WGS84: 43.97305N; 7.99425E), oliveto, 477 m, 6 April 2019, G. Barberis, A. Baroni, F. Baroni, I. Briozzo, C. Cibei, D. Dagnino, A. Giovannini, M. Leone, D. Longo, S. Peccenini, E. Rodi, V. Terzo (GE No. 1512, FI). - Species new for the flora of Liguria.

This species is poorly known in Italy, and it has only recently been reported in Veneto, Emilia-Romagna, Lazio, Abruzzo, Molise, and - not confirmed - in Sardegna (Bartolucci et al. 2018, 2019).

I. Briozzo, D. Longo, S. Peccenini 


\section{Nomenclatural and distribution updates from other literature sources, and corrigenda}

Nomenclatural and distribution updates, and corrigenda to Bartolucci et al. (2018) are provided in Suppl. material 1.

F. Bartolucci, G. Galasso

\section{Acknowledgements}

We gratefully acknowledge the following colleagues who provided distribution, nomenclatural, and taxonomic advice: Sebastiano Andreatta, Gianluigi Bacchetta, Liliana Bernardo, Francesco Bianchini, Giacomo Calvia, Francesco Di Carlo, Lorenzo Gallo, Duilio Iamonico, Roberto R. Masin, Lorenzo Peruzzi, Romeo Di Pietro, Simonetta Fascetti, Federico Mangili, Angelo Troìa, Antonio Romano.

\section{References}

Arrigoni PV (2010) Flora dell'Isola di Sardegna, Vol. 2. Carlo Delfino Editore, Sassari, 624 pp. Arrigoni PV (2013) Flora dell'Isola di Sardegna, Vol. 4. Carlo Delfino Editore, Sassari, 584 pp. Arrigoni PV (2020) Flora analitica della Toscana, Vol. 7. Ed. Polistampa, Firenze, 476 pp.

Bagella S, Becca G, Bedini G, Caria MC, Pisanu S, Urbani M, Usai MF, Filigheddu R (2020) Why so different? A case study about Floras from a Mediterranean island. Phytotaxa 440(2): 129-158. https://doi.org/10.11646/phytotaxa.440.2.4

Bartolucci F, Domina G, Alessandrini A, Angiolini C, Ardenghi NMG, Bacchetta G, Banfi E, Bolpagni R, Bonari G, Bräuchler C, Calvia G, Cancellieri L, Cannucci S, Carruggio F, Conti F, Cavallaro V, Fanfarillo E, Ferretti G, Festi F, Fiaschi T, Foggi B, Forte L, Fröhner SE, Galasso G, Gestri G, Gottschlich G, Labadessa R, Lastrucci L, Lazzaro L, Mereu G, Morabito A, Mugnai M, Musarella CM, Orsenigo S, Pazienza G, Pennesi R, Peruzzi L, Pierini B, Podda L, Prosser F, Rossi G, Scoppola A, Spampinato G, Stinca A, Tomaselli V, Zangari G, Nepi C (2019) Notulae to the Italian native vascular flora: 7. Italian Botanist 7: 125-148. https://doi.org/10.3897/italianbotanist.7.36148

Bartolucci F, Peruzzi L, Galasso G, Albano A, Alessandrini A, Ardenghi NMG, Astuti G, Bacchetta G, Ballelli S, Banfi E, Barberis G, Bernardo L, Bouvet D, Bovio M, Cecchi L, Di Pietro R, Domina G, Fascetti S, Fenu G, Festi F, Foggi B, Gallo L, Gottschlich G, Gubellini L, Iamonico D, Iberite M, Jiménez-Mejías P, Lattanzi E, Marchetti D, Martinetto E, Masin RR, Medagli P, Passalacqua NG, Peccenini S, Pennesi R, Pierini B, Poldini L, Prosser F, Raimondo FM, Roma-Marzio F, Rosati L, Santangelo A, Scoppola A, Scortegagna S, Selvaggi A, Selvi F, Soldano A, Stinca A, Wagensommer RP, Wilhalm T, Conti F (2018) An updated checklist of the vascular flora native to Italy. Plant Biosystems 152(2): 179-303. https://doi.org/10.1080/11263504.2017.1419996 
Bertoloni A (1850-1853) Flora Italica, Vol. 8. Ex Typographaeo Haeredum Richardi Masii, Bononiae [Bologna], 660 pp.

Bracchi G, Romani E (2010) Checklist aggiornata e commentata della flora della Provincia di Piacenza. Museo Civico di Storia Naturale di Piacenza, Piacenza.

De Notaris G (1844) Repertorium florae ligusticae. Ex Regia Typographia, Taurini [Torino], 495 pp. https://doi.org/10.5962/bhl.title.6657

Del Prete C, Tomaselli M (1982) Note sulla flora e vegetazione della torbiera «I Paduli» presso Fociomboli (Alpi Apuane). Atti della Società Toscana di Scienze Naturali, Memorie, serie B 88(1981): 343-358.

Desfayes M (2008) Flore vasculaire herbacée des eaux douces et des milieux humides de la Sardaigne. Flora Mediterranea 18: 247-331.

Fiori A (1923) Nuova Flora Analitica d'Italia, Vol. 1(3). Tipografia di M. Ricci, Firenze, 321-480.

Galasso G, Conti F, Peruzzi L, Ardenghi NMG, Banfi E, Celesti-Grapow L, Albano A, Alessandrini A, Bacchetta G, Ballelli S, Bandini Mazzanti M, Barberis G, Bernardo L, Blasi C, Bouvet D, Bovio M, Cecchi L, Del Guacchio E, Domina G, Fascetti S, Gallo L, Gubellini L, Guiggi A, Iamonico D, Iberite M, Jiménez-Mejías P, Lattanzi E, Marchetti D, Martinetto E, Masin RR, Medagli P, Passalacqua NG, Peccenini S, Pennesi R, Pierini B, Podda L, Poldini L, Prosser F, Raimondo FM, Roma-Marzio F, Rosati L, Santangelo A, Scoppola A, Scortegagna S, Selvaggi A, Selvi F, Soldano A, Stinca A, Wagensommer RP, Wilhalm T, Bartolucci F (2018) An updated checklist of the vascular flora alien to Italy. Plant Biosystems 152(3): 556-592. https://doi.org/10.1080/11263504.2018.1441197

Giau M (1986) Indagine floristica e vegetazionale sullo stagno di Platamona (Sardegna Nordoccidentale). Bollettino della Società Sarda di Scienze Naturali 25: 97-123.

Gigante D, Bagella S, Bonini F, Caria MC, Gabellini A, Gennai M, Rivieccio G, Viciani D (2019) New national and regional Annex I Habitat records: \#9-\#12. Plant Sociology 56(2): 129-134.

Gismondi A (1949) Prospetto della flora ligustica. Guida botanica della Liguria: descrizione succinta disposta in chiavi analitiche di tutte le piante vascolari che crescono spontaneamente sul suolo ligure, o vi si incontrano subspontanee o naturalizzate, oppure vi sono estesamente coltivate. Scia, Genova, 912 pp.

Grau J (1964) Die Zytotaxonomie der Myosotis-alpestris-und der Myosotis-silvatica-Gruppe in Europa. Oesterreichische Botanische Zeitschrift 111(5): 561-617. https://doi. org/10.1007/BF01448232

Hand R (2001) Revision der in Europa vorkommenden Arten von Thalictrum subsectio Thalictrum (Ranunculaceae). Botanik und Naturschutz in Hessen 9: 1-358.

Iamonico D (2015) Taxonomic revision of the genus Amaranthus (Amaranthaceae) in Italy. Phytotaxa 199(1): 1-84. https://doi.org/10.11646/phytotaxa.199.1.1

Licht W (2018) Conspectus florae garganicae praecursor. https://plants1.iome.unimainz.de/ files/2019/05/Conspectus.pdf [accessed 31.07.2020]

Licht W, Wagensommer RP (2020) Flora vascolare del Gargano e delle Isole Tremiti. Chiavi analitiche per la determinazione. Grenzi ed., Foggia, 955 pp.

Marhold K (2011+) Veronica L. In: Euro+Med Plantbase - the information resource for EuroMediterranean plant diversity. http://ww2.bgbm.org/EuroPlusMed/ [accessed 04.08.2020] 
Mattirolo O (1893) Paronychia cymosa In: Penzig O (Ed.) Atti del Congresso Botanico Internazionale di Genova 1892. Tipografia del R. Istituto Sordo-Muti, Genova, 398-399.

Orrù G, Angius R, Fanni S, Lastrucci L (2020) Nuove segnalazioni floristiche italiane 8. Flora vascolare (63-66). Notiziario della Società Botanica Italiana 4(1): 33-37.

Palanza A (1900) Flora della Terra di Bari. In: Jatta A (Ed.) La Terra di Bari sotto l'aspetto storico, economico e naturale. Pubblicazione della provincia di Bari per l'esposizione universale di parigi, Vol. 3. Tipografia V. Vecchi, Trani, 153-244.

Pavarino GL (1915) Intorno alla flora del calcare e del serpentino nell'Appennino bobbiese. Atti Istituto Botanico e Laboratorio Crittogamico Università di Pavia I contribuzione: ser. 2, 12: 21-56.

Pavesi V (1906) Elenco di piante dell'alto Appennino pavese. Atti Società Italiana Scienze Naturali Museo Civico di Storia Naturale Milano 45: 45-54.

Pignatti S, Guarino R, La Rosa M (2017) Flora d'Italia. Ed. 2, Vol. 2. Edagricole, Bologna.

Pignatti S, Guarino R, La Rosa M (2018) Flora d'Italia. Ed. 2, Vol. 3. Edagricole, Bologna.

Soriano Martin C (1997) Chaetonychia (DC.) Sweet In: Castroviejo S, Aedo C, Laínz M, Muñoz Garmendia F, Nieto Feliner G, Paiva J, Benedí C (Eds) Flora iberica, Vol 2. Real Jardín Botánico, CSIC, Madrid, 134-136.

Walters SM, Webb DA (1972) Veronica L. In: Tutin TG, Heywood VH, Burges NA, Moore DM, Valentine DH, Walters SM, Webb DA (Eds) Flora Europaea, Vol. 3. Cambridge University Press, Cambridge, 242-251.

\section{Supplementary material I}

\section{Supplementary data}

Authors: Fabrizio Bartolucci, Gabriele Galasso

Data type: species data

Explanation note: 1. Nomenclatural updates; 2. Note updates; 3. Distribution updates; 4. Synonyms, misapplied or included names.

Copyright notice: This dataset is made available under the Open Database License (http://opendatacommons.org/licenses/odbl/1.0/). The Open Database License $(\mathrm{ODbL})$ is a license agreement intended to allow users to freely share, modify, and use this Dataset while maintaining this same freedom for others, provided that the original source and author(s) are credited.

Link: https://doi.org/10.3897/italianbotanist.10.60743.suppl1 